\title{
INTERNATIONAL CONFLICT OF LAWS: LIMITATIONS IMPOSED ON EFFECT AMERICAN COURTS MAY GIVE TO FOREIGN CONFISCATIONS
}

\begin{abstract}
Where a foreign government purports to confiscate its citizen's assets although located within the United States, the Second Circuit has held that both federal and state courts must deny effect to the confiscation unless it is consistent with United States law and policy. This result obtains because such a confiscatory decree constitutes an "act of state" within the category of actions deemed by the Supreme Court in Sabbatino to necessitate a uniform federal rule.
\end{abstract}

A IMPORTANT FEATURE of Banco Nacional de Cuba v. Sabbatino, ${ }^{1}$ decided by the Supreme Court in 1964, was its holding that the Act of State doctrine ${ }^{2}$ is a matter of federal law binding upon the states. 3 That doctrine, as articulated by the Court, provides that "the Judicial Branch will not examine the validity of a taking of property within its own territory by a foreign sovereign government ....." While the Court carefully circumscribed its enunciation of the doctrine, 5 the principle of federal supremacy underlying Sabbatino now

1376 U.S. 398 (1964). See generally Falk, The Complexity of Sabbatino, 58 AM. J. INT'L LAw 935 (1964); Henkin, The Foreign Affairs Power of the Federal Courts: Sabbatino, 64 CoLum. L. Rev. 805 (1964); Mann, The Legal Consequences of Sab. batino, 51 VA. L. REv. 604 (1965); Metzger, Act of State Doctrine Refined: The Sab. batino Case, 1964 Sup. CT. REv. 223; Reeves, The Act of State-Foreign Decisions Cited in the Sabbatino Case: A Rebuttal and Memorandum of Law, 33 FordiaM L. Rev. 599 (1965); Reeves, The Sabbatino Case: The Supreme Court of the United States Rejects a Proposed New Theory of Sovereign Relations and Restores the Act of State Doctrine, 32 ForDhaM L. REv. 631 (1964); Wright, Reflections on the Sab. batino Case, 59 AM. J. INT'L LAw 304 (1965); Comment, 63 Mich. L. Rev. 528 (1965).

${ }^{2}$ See generally Falk, The Role of Domestic Courts in the INTERNational Legal ORDER (1964); Baade, The Legal Effect of Cuban Expropriations in the United States, 1963 Duke L.J. 290; Falk, The Case of Banco Nacional de Cuba v. Sabbatino Before the Supreme Court of the United States, 9 How. L.J. 116 (1963); Metzger, The Act of State Doctrine and Foreign Relations, 23 U. PITT. L. REv. 881 (1962); Comment, 62 Colum. L. Rev. 1278 (1962).

3376 U.S. at $425-27$.

4 Id. at 428.

- The Act of State doctrine might still not be applicable if an existing treaty or "unambiguous agreement" governs the taking; if the foreign government no longer exists or is not recognized by the United States at the time of suit; if the property affected was not within the taking country's territory; or if the Executive suggests that the doctrine need not be applied. 376 U.S. at 428. Other limitations on the holding have been suggested. See Falk, The Complexity of Sabbatino, 58 AM. J. INT'L LAW 935, 939.46 (1964). 
seems to have been greatly expanded by the Second Circuit Court of Appeals in Republic of Iraq v. First National City Bank.'

The Iraq case involved the assets of King Faisal II of Iraq, who was killed in the course of a revolution in that country in 1958. Immediately after his death the succeeding revolutionary government promulgated Ordinance No. 23, which purported to confiscate all property owned by the royal family, wherever located. ${ }^{7}$ At the time of King Faisal's death he had cash and securities on deposit with Irving Trust Company in New York. The Iraqi Government demanded these assets but Irving refused to accede and transferred them to the First National City Bank of New York, which had obtained letters of administration from the New York County Surrogate's Court with respect to the King's New York property. To recover this property, the Republic of Iraq brought suit against First National City Bank in the federal district court for the Southern District of New York. ${ }^{8}$

The district court did not decide whether New York law or federal law was controlling but held that in either case recovery should be denied on the basis of the two familiar conflict of laws doctrines that a forum will not enforce foreign laws which are either penal in nature or which contravene the forum's public policy. ${ }^{9}$ The Second Circuit, in a unanimous opinion, affirmed. Writing for the court, Judge Friendly first characterized Ordinance No. 23 as confiscatory and thus an act of state, ${ }^{10}$ although he recognized that the traditional Act of State doctrine was inapplicable since the property confiscated was not physically located within the acting country. ${ }^{11} \mathrm{He}$ then drew from the Sabbatino case a broad sanction for the federal courts to make law governing the legal effect to be accorded such

\footnotetext{
- 353 F.2d 47 (2d Cir. 1965), cert. denied, 382 U.S. 1027 (1966), affirming 241 F. Supp. 567 (S.D.N.Y. 1965).

The full text of the ordinance is set out in the district court opinion, 241 F. Supp. at $570-71$.

8 353 F.2d at 49.50 .

- 241 F. Supp. at 574-75. See generally Ehrenzweig, Conflict of LAws $\S 37$, at 133.34 (1962).

10 353 F.2d at 50. This characterization is sound only in the sense that the decree would be sufficient to invoke the Act of State doctrine if the property in issue had been in Iraq at the time of the taking. See Restatement, Foreign ReLATions LAW of The United States $\$ 41$, comment $c$ (Proposed Off. Draft 1962). By so characterizing the confiscation, however, the Second Circuit was able to equate the instant case with Sabbatino and thus justify the power to promulgate a rule of federal common law which the Sabbatino case had asserted in classic Act of State situations. See text accompanying notes 1.4 supra.

11353 F.2d at 50 .
} 
acts by all courts in this country, both state and federal. ${ }^{12}$ Relying on Section 46 of the Restatement of Foreign Relations Law of the United States, Friendly proceeded to promulgate the rule that a foreign act affecting property within the United States will be given effect only if "consistent with the policy and law of the United States."13 A brief examination of constitutional provisions and American traditions convinced the court that a confiscation without compensation was in fact opposed to United States law and policy and thus that the present taking could not be given legal effect.14

The opinion noted in conclusion that if the case had been brought in the state courts, established New York precedent would have dictated the same result. ${ }^{15}$ The court added, however, that the rule here formulated was binding on the states and therefore New York courts could not give the foreign decree either less or greater effect than this federal rule would indicate. ${ }^{16}$

The Sabbatino case, from which the court purported to derive its authority to promulgate exclusive federal law, involved the traditional Act of State situation: the property taken (American-owned sugar) was located in Cuba, the taking country, at the time of the confiscation. ${ }^{17}$ The Supreme Court held that the Act of State doctrine, which it characterized as a federal court-made rule binding on the states, precluded judicial re-examination of the legal validity of the taking even though the taking was alleged to have been in

12 Id. at 50-51.

${ }^{13} \mathrm{Id}$. at 51 . To support the rule that no credence will be accorded foreign acts which are violative of American public policy, and also to show that confiscations fall under it, the court referred to Zwack v. Kraus Bros. \& Co., 237 F.2d 255, 259 (2d Cir. 1956); Vladikavkasky Ry. v. New York Trust Co., 263 N.Y. 369, 189 N.E. 456 (1934); Plesch v. Banque Nationale de la Republique D'Haiti, 273 App. Div. 224, 77 N.Y.S.2d 43, aff'd, 298 N.Y. 573, 81 N.E.2d 106 (1948). Accord, Latvian State Cargo \& Passenger S.S. Line v. McGrath, 188 F.2d 1000 (D.C. Cir.), cert. denied, 342 U.S. 816 (1951); Bollack v. Societe Generale Pour Favoriser, 263 App. Div. 601, 33 N.Y.S.2d 986 (1942); A/S Merilaid \& Co. v. Chase Nat'l Bank, 189 Misc. 285, 7I N.Y.S.2d 377 (Sup. Ct. 1947). But see Anderson v. N.V. Transandine Handelmaatschappij, 289 N.Y. 9, 43 N.E.2d 502 (1942), finding a confiscation consistent with New York policy.

14 The court noted that if the ordinance had been promulgated by the Unitcd States or an American state, it would fall under the prohibitions of the fifth and fourteenth amendments and the bill of attainder clause. 353 F.2d at 51-52.

${ }^{15}$ Although a statutory choice-of-law rule, N.Y. DEced. EsT. LAw $\$ 47$, provided that the disposition of a decedent's personalty should be governed by the law of the country of his residence at the time of death, the court concluded that New York's long-standing rnle of non-recognition of confiscations contrary to public policy would be controlling. 353 F.2d at 53. See New York cases cited note 13 supra. See also Menzel v. List, 267 N.Y.S.2d 804 (Sup. Ct. 1966).

16953 F.2d at 59.

17376 U.S. at 403 . 
violation of international law.18 While the Court stated that its powers to make the rule and to bind the states by it were derived from the Constitution, it did not identify the specific constitutional provisions from which these powers originated. ${ }^{19}$ Essentially the Court asserted the power to promulgate preemptive federal law because classic Act of State cases involve two delicate elements: the interrelationships between the branches of the federal government, and the probable impact of judicial action on our ties with other nations. ${ }^{20}$ The Court apparently felt that the area of foreign relations, primarily a province of the executive branch, is so sensitive that the possibilities for destructive consequences are too great if judicial decisions are made on the merits of foreign confiscation decrees; ${ }^{21}$ hence the Act of State rule, which in effect requires all courts in the United States to assume, without deciding, that such decrees are legally binding. It is said that the rule not only. prevents possible upsetting of the conduct of foreign relations by judicial decision, but also gives the State Department the ability. to negotiate with other nations with greater confidence and freedom, secure in the knowledge that no court decision will embarrass it in its pursuits. ${ }^{22}$

The essential factual distinction in Iraq is that the affected property was located within the United States at the time of the taking. Judge Friendly, reading Sabbatino expansively, concluded that since under the facts of Iraq our foreign relations could similarly be affected by judicial decision, he was justified in again fashioning a federal rule which would constitute uniform law in the United States. ${ }^{23}$ Beyond Sabbatino, his opinion adduces no significant authority for this ruling; apparently the Iraq situation has never before been thought to be controlled by federal law. ${ }^{24}$ For analogous

\footnotetext{
${ }^{18} I d$. at 428 .

${ }^{10}$ Id. at 427 n.25. See Henkin, supra note 1 , at $814-26$, for a thorough discussion of possible constitutional theories.

20376 U.S. at 425 .

21 Id. at 423, 431-33.

${ }^{39}$ See Metzger, The Act of State Doctrine and Foreign Relations, 23 U. PITT. L. REv. 881 (1962). The doctrine as outlined in Sabbatino has been effectively overruled by Congress. Foreign Assistance Act of 1964, 78 Stat. 1013, as amended, 22 U.S.C.A. $\$ 2370$ (e) (2) (Supp. 1965). See note 49 infra and accompanying text. It is conceivable that the Second Circuit was influenced by knowledge of this statute in formulating a substantive rule opposed to the philosophy of Sabbatino.

23353 F.2d at 50-51.

${ }^{21}$ See cases cited note 13 supra. It should be noted, however, that the classic Act of State doctrine was not regarded as an exclusively federal province until Sabbatino.
} 
support Friendly cited scholarly discussions of interstate stream dispute cases and decisions concerning rights under federally-issued negotiable instruments; ${ }^{25}$ but while these situations do illustrate the promulgation of federal common law, the theories of constitutional power on which they rest are far removed from the problem of foreign relations involved in Iraq and Sabbatino. ${ }^{26}$

The very reasons Friendly uses to justify his power to make federal law serve also to illustrate the fallacy of the substantive law he proceeds to create. For if it is true here, as in the Sabbatino situation, that judicial decisions on the merits of a foreign decree may affect our foreign relations, then the only safe course, as the Sabbatino court said, must be to preclude examination of that decree by domestic courts altogether. ${ }^{27}$ As Mr. Justice Harlan expressed it, the rationale behind the Act of State doctrine is that the judiciary's "task of passing on the validity of foreign acts of state may hinder rather than further this country's pursuit of goals . . . ."28 Further, Judge Friendly's opinion painstakingly emphasized the point that the decree in Iraq was "an act of state."20 Yet the rule he lays down in Iraq not only allows, but compels domestic courts to pass on the validity of such acts by measuring them against the

25353 F.2d at 51 n.2. The authorities cited are Wright, FEDERAL CourTs $\S 60$, at 214 (1963); Friendly, In Praise of Erie-and of the New Federal Common Law, 39 N.Y.U.L. REv. 383, 408-09 \& n.119 (1964); Henkin, supra note 1, at 826-30. Sce also Clearficld Trust Co. v. United States, 318 U.S. 363 (1943) (federal paper); Hinderlider v. LaPlata River \& Cherry Creek Ditch Co., 304 U.S. 92, 110 (1938) (stream dispute).

${ }^{28}$ In both of the types of cases mentioned, the Constitution grants a power to the federal government without specifying what law is to govern the exercise of that power. U.S. CoNST. art. I, $\S 8$ (2) (granting Congress power to borrow); U.S. CoNST. art. III, $\S 2$ (granting Supreme Court original jurisdiction of disputes between states). Therefore a federal common law is presumably required. On the other hand, the substantive rules promulgated in Iraq and Sabbatino are obviously not required to fill any vacuum created by the constitutional grant of foreign relations power to the federal executive. They are merely thought to make the exercise of that power more efficient by controlling the judicial handling of cases which may have an incidental impact on foreign relations.

${ }^{27}$ The Sabbatino Court did acknowledge that "we do not now pass on the Bernstein exception" a rule derived from Bernstein v. N.V. Nederlandsche-Amerikaansche Stoomvaart-Maatschappij, 210 F.2d 375 (2d Cir. 1954) (per curiam), and which allows a court to disregard the Act of State doctrine when advised tbat the Exccutive has no objection to its doing so. 376 U.S. at 436. See Kane v. National Institute of Agrarian Reform, 18 Fla. Supp. 116, 120 (Cir. Ct. 1961). Thus, although Sabbatino's strong assertion of judicial independence in such cases may be viewed as tundermining a rule which is posited upon a modicum of judicial deference to executive pronouncement, the Bernstein exception is still a precedentially tenable rule at present.

28376 U.S. at 423.

so 353 F.2d at 50 . 
standard of "United States law and policy" where the affected property is within the United States at the time of the confiscatory decree. Such a rule seems bluntly to contradict the philosophy of abstention propounded by Sabbatino.

In reply it may be contended that a judicial decision on the merits of a confiscation of the Iraq type is not nearly so likely to interfere with the conduct of foreign affairs as a ruling on the validity of a confiscation affecting property located within the taking country. Insofar as such interference might arise because the decision is regarded by the acting sovereign as insulting, this will typically be true. In the case of an extra-territorial confiscation, the foreign government has much less reason to expect blind recognition from courts in the United States. Territorial notions of sovereignty weigh heavily and where a nation lacks territorial jurisdiction at the time of the confiscating decree, it has little standing to complain of non-recognition by a country which did have such jurisdiction. ${ }^{30}$ Such a decision seems less likely to "vex the peace of nations." 31

However, whether interference with the State Department's goals will occur in a given case is quite another question. ${ }^{32}$ Suppose some property falling under the decree (even if not the specific property under litigation) comes into the hands of the foreign government and the United States executive is negotiating for redress of the rights of the original owner, who may be a United States citizen. A judicial holding, particularly by a federal court, that the decree is "consistent with the law and policy of the United States" might seriously weaken the Executive's bargaining position; conversely, a judicial refusal to recognize the decree might be offensive enough to chill negotiations and lessen the probabilities of a favorable settlement. ${ }^{33}$ In the Iraq case itself no such negotiations were being conducted, but a contrary situation is not farfetched. Indeed, if the United States is conducting sufficiently sensitive negotiations with the confiscating country on an entirely unrelated matter, a decision on the merits of an existing confiscation decree might be highly upsetting.

Whether an embarrassing judicial decision is actually forth-

so 376 U.S. at 432; see Henkin, supra note 1, at 828 n.80 and cases cited therein; Restatement, foreign Relations LAW of THE United States \$\$ 11-25 (Proposed Off. Draft 1962).

${ }^{31}$ Quoting from Oetjen v. Central Leather Co., 246 U.S. 297, 304 (1918).

32 See Henkin, supra note 1 , at 828.

${ }^{33}$ Cf. 376 U.S. at $432-33$. 
coming or not, the very prospect of such a decision to some extent ties the hands of the Executive in sensitive cases. Given the possibility of a decision of this nature, United States diplomatic negotiators cannot proceed with full confidence and assurance; they must act gingerly, constantly mindful of the possibility of an adverse court holding. It may be thought that such cases will not occur frequently, but that fact scarcely serves to minimize these problems when they do arise.

If the result of the Second Circuit's substantive rule is not to aid the operations of the national executive, it nonetheless benefits other United States interests. For the court observes that

"Foreigners entrusting their property to custodians in this country are entitled to expect this historic policy [of opposition to confiscations] to be followed save when the weightiest reasons call for a departure." 34

Underlying this statement may be the realization that it is to the advantage of United States citizens to encourage foreign investors to place their assets with American financial institutions, and that protection of those assets from confiscation is a part of that encouragement. The rule of the case accrues directly to the economic benefit of American banks and trust companies and their owners, and also tends to restore a favorable international balance of payments to the United States by inducing a greater flow of foreign capital into this country. Moreover, it is at least arguable that this latter interest does fall into the category of problems associated with "our relations with other members of the international community"35 -the only problems with which the Supreme Court in Sabbatino said justified exclusive federal control.

The substantive rule the court propounded was derived from section 46, Restatement of Foreign Relations Law of the United States. ${ }^{36}$ It is closely related to the "public policy exception" found

\footnotetext{
34353 F.2d at 52.

35376 U.S. at 425 .

"36 "\$ 46. Acts of Foreign State Affecting Interests Outside Territory

"(1) The rule stated in $\S 41$ [the Act of State doctrine] does not prevent examination of the validity of an act of a foreign state with respect to things located, or other interests localized, within the territory of another state even though the acting state had jurisdiction to take the action under the rules stated in the Restatement of this Subject.

"(2) Courts in the United States give effect to acts described in Subsection (1) of this Section only if they are consistent with the policy and law of the United States." Restatement, Foreign Relations LAW of the United States $\$ 46$ (Proposed Off. Draft 1962).
} 
in conflict of laws doctrine ${ }^{37}$ and has long been applied by United States courts, as well as courts of a number of other nations, in dealing with foreign conflscations of property within the forum. ${ }^{38}$ However, it does not appear, and the Restatement does not imply, that the public policy rule has ever been viewed as a matter of federal law which binds the states. The Second Circuit's holding in Iraq is unique in this regard, and was achieved through the characterization of the decree at issue as an "act of state" having ramifications for the conduct of foreign relations. ${ }^{39}$

Like the "public policy exception," the rule of section 46 is far from easy to apply with precision and consistency. Judge Friendly thought Ordinance No. 23 inconsistent with American law and policy, reasoning that if it had been enacted by an American state or the federal government, it would clearly contravene the fifth and fourteenth amendments and the bill of attainder clause. 10 Yet his opinion sheds no light on the question of whether those constitutional provisions are always to be mechanically applied full-force to test the validity of an act of a foreign state whose internal constitutional limitations may differ fundamentally from our own.41 A test based on an attenuated version of the Constitution might prove difficult to apply; for example, hypothesize a case like Iraq with the exception that some compensation is paid, although not an adequate amount by United States standards; or suppose a confiscation not discriminatory in nature, but equally applicable to all Iraq citizens. These situations seem somewhat less obnoxious to our Constitution and pose the question of how inconsistent with United States law and policy the foreign decree must be. Past state court decisions offer little gnidance, for they are characteristically ambiguous and apply state rather than federal standards. ${ }^{42}$ The test is subject to the same criticisms of irrelevance to the question of forum interest, inexactitude, and judicial manipulation which have been

\footnotetext{
${ }^{a 7}$ This "exception" states that, notwithstanding other conflicts rules, a foreign law will not be given effect if it is contrary to a strong public policy of the forum. See generally Loucks v. Standard Oil Co., 224 N.Y. 99, 120 N.E. 198 (1918); Katzenbach, Conflicts on an Unruly Horse: Reciprocal Claims and Tolerances in Interstate and International Law, 65 YALE L.J. 1087 (1956); Paulsen \& Sovern, Public Policy and the Conflict of Laws, 56 CoLum. L. Rev. 969 (1956).

${ }^{\text {as }}$ See cases cited note 13 supra; Grzybowski, Public Policy and Soviet Law in the West After World War II, 4 AM. J. Comp. L. 365 (1955).

"See note 10 supra and accompanying text.

to 353 F.2d at 51-52.

$\$ 1$ Id. at 52.

"2 See cases cited note 13 supra.
} 
levied against the "public policy exception" in its more mundane domestic setting. ${ }^{43}$

Perhaps a more workable and predictable approach to foreign confiscations can result from application of the principle of governmental interest analysis which has been advocated by leading scholars in the field of domestic choice of law.44 According to one proponent of this principle, it is a basic premise that the forum will apply its own law if it has any governmental interest in doing so. If no such interest is discernible, the law of the interested foreign jurisdiction will be given effect. ${ }^{45}$ In pursuing such an analysis, it should be noted that two peculiar features appear in foreign confiscation cases which are not present in purely domestic choice of law problems. First, the forum interest which is to be taken into account may include both federal and state interests. It would seem that when the opposing law is that of a foreign nation, both federal and state courts should regard either a federal or state interest as a "forum" interest. If federal and state interests conflict in such a way as to bear significantly on United States foreign relations, the teaching of Sabbatino is that the federal interest must predominate. ${ }^{48}$

A second feature peculiar to foreign confiscations is that the forum interest in a given case may be advanced either by upholding the foreign decree without examination or by examining and possibly rejecting it. The major federal interests which might be asserted in a judicial refusal to examine the foreign decree include the facilitation of executive negotiations and the avoidance of offense to the foreign sovereign. Both of these interests are attributable to the national executive; neither federal nor state judges are competent to estimate their extent in a given case. ${ }^{47}$ Both interests may be present in cases of extra- as well as intra-territorial confiscations. An efficacious rule from the judiciary's point of view would be a presumption of the absence of any interest which would be furthered by not adjudicating the validity of the decree unless the executive, upon adequate notice, advises the court of its desire that the decree

\footnotetext{
${ }^{43}$ See Katzenbach, supra note 37; Paulsen \& Sovern, supra note 37.

"See generally Cavers, The Choice of Law Process (1965); Currle, Selectrd essays on the Conflict of Laws (1963); Comment, 63 Colum. L. Rev. 1212 (1963); Note, 1965 DukE L.J. 623.

45 CURRIE, op. cit. supra note 44 , at $183-84$.

40376 U.S. at $425 \cdot 27$.

"7 See Cardozo, Judicial Deference to State Department Suggestions: Recognition of Prerogative or Abdication to Usurper, 48 CoRNErL L.Q. 461, 479 (1963); Katzenbach, supra note 37 , at 1153.54 .
} 
be upheld without examination. ${ }^{48}$ While the State Department, in the course of the Sabbatino Jitigation, objected to the imposition of this burden upon it, ${ }^{49}$ Congress has nevertheless imposed it by statute by dictating that, unless the President advises to the contrary, the courts are to disregard the Act of State doctrine if the confiscation in question was in violation of international law. ${ }^{\mathbf{5 0}}$ It seems improbable that the additional onus on the State Department which would result from broadening this rule to include cases of extra-territorial confiscations would be objectionable.

The possibility of an exception to Judge Friendly's "public policy" rule for executive suggestions may be implicit in his acceptance $^{51}$ of United States $v$. Belmont ${ }^{52}$ and United States $v$. Pink, ${ }^{53}$ in which the Supreme Court forbade judicial re-examination of

${ }^{18}$ Cf. Committee on Int'l Law, New York City Bar Ass'n, Resolution, 14 Record of N.Y.C.B.A. 228 (1959). An executive suggestion that a confiscating decree be upheld without examination might be denoted a "reverse Bernstein" rule. See note 27 supra.

${ }^{\circ}$ Brief for Department of State as Amicus Curiae. See also Hearings on the Foreign Assistance Act of 1964 Before the Senate Foreign Relations Committee, 88th Cong., 2d Sess. 618-19 (1964) (statement of the Executive Department objecting to proposed statute).

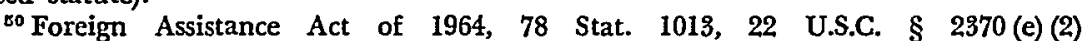
(1964). See generally 59 AM. J. INT'L L. 366 (1965); 65 Colum. L. REv. 530 (1965); 10 VILL. L. REv. 509 (1965). The 1965 amendment makes the statute permanent. The House Committee held extensive hearings and heard divergent testimony by a number of distinguished witnesses. Hearings on the Foreign Assistance Act of 1965 Before the House Foreign Affairs Committee, 89th Cong., lst Sess. (1965). The divergency is illustrated by comparing the testimony of Professor Olmstead, id. at 576, with that of Professor Henkin, id. at 1060. An interesting shift of position is evident by comparing the testimony of Attorney General Katzenbach, id. at 1234, with Katzenbach, supra note 37 , at $1153-54$.

The amendment as originally adopted by the Senate Foreign Relations Committee would have suspended operation of the Act of State doctrine (absent an objection from the President) if a violation of international law were merely alleged. See S. REP. No. 1188, pt. 1, 88th Cong., 2d Sess. 24 (1964); Metzger, The Act-of-State Doctrine Refined, 1964 SuP. CT. REv. 223, 242 n.50. The conference version which was ultimately passed was altered to "make it clear that it [the amendment] does not apply if no violation of international law principles is found . ..." H.R. REP. No. 1925, 88th Cong., 2d Sess. (1964), reprinted in U.S. CODE Cong. \& AD. NEws 3890 (1964). (Emphasis added.) Presumably, this means that a court must determine as a preliminary question the existence of a violation and only if one is found is submission to executive suggestion required. Yet this "preliminary determination" seems tantamount to adjudication on the merits of the confiscation, the very thing the Act of State doctrine and the statutory provision for deference to the President are designed to avoid. The only case yet decided under the statute is the Sabbatino case on remand, where the district court held that it need not make a preliminary finding as to whether international law had been violated, since the Second Circuit in the course of the previous appeal had already found such a violation. Banco Nacional de Cuba v. Farr, 243 F. Supp. 957, 979-80 (S.D.N.Y. 1965), 6 VA. J. INT'L L. 173.

51353 F.2d at 52.

c2 301 U.S. 324 (1937).

Es 315 U.S. 203 (1942). 
Soviet confiscations of property in the United States which had subsequently been ratified by executive agreements between the two nations. ${ }^{54}$ Essentially the same reasons exist for giving predominance to the Executive's wishes whether or not they have been embodied in a formal agreement. ${ }^{55}$ It is probably unnecessary to require that the executive suggestion be given conclusive weight; the desired result can be accomplished if it is given, as a matter of federal law, "great weight" as evidence of the existence of a federal interest in nonadjudication, in somewhat the same way that executive suggestions of sovereign immunity are handled. ${ }^{60}$

In the absence of such a suggestion, at least two interests in denying effect to the foreign confiscation may exist. If the owner of the property taken is a United States citizen, both federal and

os Id. at 230-32; 301 U.S. at 326-27, 331-32. See generally Stevenson, Effect of Recog. nition on the Application of Private International Law Norms, 51 Colum. L. REv. 710, 719 (1951).

or See Cardozo, supra note 47, at 479. Judge Friendly's opinion does not wholly foreclose the possibility of a court's deferring to an executive suggestion given outside the context of a formal agreement. He noted that in Iraq the State Department had disclaimed any objection to adjudication on the merits, but he failed to con. sider what effect an expression of contrary desire by the Executive might have. 353 F.2d at 52. Judge McLean's opinion in the district court strongly hinted that such an expression might be given some weight. $241 \mathrm{~F}$. Supp. at 573, 575. Compare Latvian State Cargo \& Passenger S.S. Line v. McGrath, 188 F.2d 1000, 1003 (D.C. Cir. 1951), holding conclusive a state department statement that the confiscation in question should not be recognized, with Anderson v. N.V. Transandine Handelmaatschappij, 289 N.Y. 9, 43 N.E.2d 502 (1942), in which the court, while doubtless influenced by the State Department's suggestion that the confiscation should be recognized, refused to give it conclusive weight and instead purported to find independently that the confiscation was consistent with New York public policy. See Zwack v. Kraus Bros. \& Co., 93 F. Supp. 963, 966 (S.D.N.Y. 1950), which implies that effect would be given to an expression by the executive that United States policy requires recognition of a foreign confiscation of property within the United States.

The grant of immunity to a sovereign whose person or property is the subject of suit is in effect a covariant of executive will. The Supreme Court has ruled that the federal courts are bound by a "recognition and allowance" by the State Department of a claim of immunity. Ex parte Republic of Peru, 318 U.S. 578, 588 (1943). In the absence of a formal suggestion the Court has stated that failure of tbe State Department to allow a claim of immunity is an "important reason" for denying it. Republic of Mexico v. Hoffman, 324 U.S. 30, 35 n.1 (1945). The State Department does not, doubtless as a matter of courtesy, classify its certifications as judicially unassailable: "It is realized that a shift in policy by the executive cannot control the courts but it is felt that the courts are less likely to allow a plea of sovereign immunity where the executive has declined to do so." Letter from acting Legal Adviser of State Department to acting Attorney General, May 19, 1952, in 26 DEP'T STATE Bul. 984, 985 (1952). See Rich v. Naviera Vacuba, S.A., 197 F. Supp. 710, 724-25 (E.D. Va.), aff'd, 295 F.2d 24 (4th Cir. 1961) (per curiam). See generally Cardozo, supra note 46, at 469.76; Cardozo, Sovereign Immunity: The Plaintiff Deserves a Day in Court, 67 HARv. L. REv. 608 (1954); Garcia-Mora, The Doctrine of Sovereign Immunity of Foreign States and its Recent Modifications, 42 VA. L. REv. 335 (1956). 
state governments have an interest in compensating him or minimizing his loss. If the owner is a foreigner who entrusted his property to an American custodian in reliance on the protection of United States law, both federal and state governments arguably have economic interests in providing that protection. 57 In both of the above situations, the foreign decree should be upheld only if it complies fully with the standards of the Constitution; no attenuated test will uphold the reasonable expectations of foreign investors or adequately protect the interests of American owners. If no United States or state interests are perceived by the court, it should give effect to the foreign decree without further inquiry into United States "policy" regarding confiscations. The interest-analysis approach described here thus has an additional advantage over the method of invoking, as the Iraq court does, the catchall rubric of public policy; such a mechanical adjudicatory technique may result in the invalidation of a foreign decree when in fact no United States interest exists that will be served by doing so. ${ }^{58}$

In the light of the Supreme Court's expressions in Sabbatino of aversion to judicial deference to executive suggestion, ${ }^{59}$ it is unlikely that the technique described above will be adopted by judicial decision. It is possible, however, that a future case with sufficiently vital foreign affairs ramifications might prompt congressional action in promulgating such a rule. Indeed, the maguitude of the Sabbatino ruling precipitated a similar legislative rebuke. ${ }^{60}$

It is undeniable that the method here suggested for judicial disposition of cases arising from extra-territorial confiscations, like the current approach to confiscations of property within the acting state dictated by Sabbatino and its statutory amendment, has the regrettable effect of occasionally sacrificing the interests of meritorious litigants in American courts for the convenience, and perhaps the necessity, of giving the State Department free reign in the

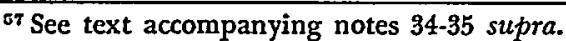

${ }^{58}$ For example, suppose a cargo of sugar owned by a Cuban national is being shipped from Cuba to China aboard an Indonesian freighter. While the vessel is anchored in the port of New York to discharge other cargo, the Castro government issues a decree confiscating the sugar. A representative of the Cuban government attaches and brings suit in a New York court to establish its title against the original owner. Here no apparent American interest would be served by refusal to recognize the confiscation; yet according to Judge Friendly's formulation, it violates United States policy and thus is not cognizable in any United States court.

50376 U.S. at 436.

${ }^{\circ}$ Sce note 22 supra.
} 
conduct of foreign relations. A satisfactory ultimate resolution of this conflict of interest seems beyond the scope of judicial power; perhaps it can be accomplished only by a congressional decision to compensate the hapless litigant from federal funds when the Executive's needs take precedence over his interests. To date, however, Congress has made only limited overtures in this direction.1 In any event, the judicial solution postulated above would minimize the likelihood of unnecessarily defeating the litigant's right to be heard on the merits, provided that litigant is one whom the forum has an interest in protecting.

\footnotetext{
${ }^{61}$ The Government's investment guaranty program furnishes a means for American investors to insure against foreign confiscations of their property, but the program's coverage is so uncertain and its benefits so limited that it has not proven to be of great practical importance. See Act for International Development of 1961, $\S \S 221-24,75$ Stat. 429, 22 U.S.G. § 2181-84 (1964); Armstrong, The United States Government's Investment Guaranty Program, 20 Bus. Law. 27 (1964); Scheiner, The Foreign Investment Guaranty Program, 35 PA. B.A.Q. 41 (1963).
} 